\title{
PEMBUATAN ETANOL DARI LIMBAH KULIT KETELA (Manihot esculenta crantz) OLEH AKTIVITAS FUNGI
}

\author{
Putra Adyasa Jatnika, R. Ratnaningsih, Astri Rinanti \\ Jurusan Teknik Lingkungan, Fakultas Arsitektur Lanskap dan Teknologi Lingkungan, \\ Universitas Trisakti, Jakarta, Indonesia
}

Email korespondensi: putra08215046@std.trisakti.ac.id

\begin{abstract}
ABSTRAK
Karya ilmiah ini muncul karena banyaknya limbah kulit ketela yang terbuang dari produksi keripik ketela pada dasarnya kulit ketela masih dapat dimanfaatkan untuk menjadi sebuah energi terbaharukan yaitu etanol. Pada umumnya buah ketela di Indonesia menggunakan spesies Manihot esculenta crantz sehingga menurut karakterisisasi/komposisi kulit ketela mengandung selulosa sebesar $43.626 \%$. Tujuan dari karya ilmiah ini adalah untuk mengetahui kemampuan dari aktivitas enzimatis melalui proses hidrolisis menggunakan mikroorganisme efektif yaitu fungi dan fermentasi menggunakan ragi/khamir. Hasil dari karya ilmiah ini untuk parameter glukosa menggunakan metode DNS (3,5 - dinitrosalilisat) dan parameter etanol menggunakan metode GC - MS (Gass Chromatography - Mass Spectophotometry). Penelitian sebelumnya ini dilengkapi dengan dua tahap yaitu tahap pendahuluan yang disebut sebagai hidrolisis dengan menggunakan fungi. Kemudian tahap inti yang disebut sebagai fermentasi memanfaatkan mikroorganisme ragi/khamir. Hasil penelitian dari berbagai studi pustaka menunjukan bahwa variasi perlakuan hidrolisis dan fermentasi menyebabkan terbentuknya senyawa etanol. Adapaun hasil ratarata menunjukan bahwa etanol tertinggi didapatkan melalui proses hidrolisis fungi Aspergillus fumigatus dan fermentasi terbaik dengan menggunakan Saccharomyces cerevisae pada hari kedua menghasilkan etanol sebesar $3.76 \%(\mathrm{v} / \mathrm{v})$.
\end{abstract}

Kata Kunci: Bioetanol, Kulit ketela, Fungi

\section{PENDAHULUAN}

Salah satu solusi untuk krisis energi adalah pemanfaatan bioetanol sebagai energi alternatif. Bioetanol dapat meningkatkan efisiensi pembakaran karena mengandung 35\% oksigen di samping itu, bioetanol adalah bahan bakar yang ramah lingkungan karena tidak menghasilkan polusi gas karbon (Artiyani, 2011). Di era ini, bioetanol diproduksi dari bahan baku makanan pokok seperti molase dari tebu, jagung, dan umbi ketela. Limbah dari pertanian industri berpotensi digunakan sebagai bahan baku bioetanol karena ketersediaannya masih melimpah, biayanya relatif murah dan dapat mengurangi persaingan dengan makanan pokok (Sarkar, 2011). Produksi ketela di Indonesia mencapai 22 juta ton pada tahun 2015. Dari pengolahan ketela, limbah kulit ketela yang dihasilkan tinggi dan tidak terpakai secara optimal. Pemanfaatan kulit ketela hanya untuk pakan ternak atau dibuang begitu saja sebagai sampah. Bahan lignoselulosa dari kulit ketela dapat digunakan sebagai bahan baku untuk bioetanol (Hikmiyati, 2008). Limbah kulit ketela mengandung 43,626\% selulosa, hemiselulosa, dan lignin 10,384\% 7,646\% (Artiyani, 2011). Namun di Indonesia, produksi bioetanol terkendala oleh tingginya biaya anggaran produksi baik dalam skala industri maupun skala industri rumahan, hal ini menyebabkan konversi energi konvensional menjadi energi terbarukan tidak dapat diterapkan secara optimal di Indonesia.

Ada dua tahap utama produksi bioetanol, pertama adalah proses hidrolisis yang memecah selulosa menjadi gula sederhana dengan bantuan asam atau enzim. Kedua adalah proses fermentasi yang akan mengubah gula menjadi alkohol melalui respirasi anaerob oleh mikroba (Fachry dkk., 2013). Dalam karya ilmiah ini, fungi digunakan sebagai katalis untuk memecah reaksi lignoselulosa menjadi gula sederhana. Hidrolisis enzimatik relatif lebih efisien dalam menghasilkan gula karena dapat meminimalkan pembentukan senyawa beracun sebagai hasil dari proses hidrolisis asam. Namun, kelemahan dari metode ini adalah dibutuhkan waktu lebih lama daripada proses hidrolisis asam dan biaya tinggi bahan enzim yang dimurnikan (Novia, 2011).

Berdasarkan komposisi kulit ketela sebagai biomassa lignoselulosa, fungi memiliki kandungan enzim yang sesuai, yang dapat digunakan pada proses hidrolisis enzimatik seperti Galactosidase, xylanase, Galaktomananase, $\beta$-glucosidase, amylase. Enzim Galactosidase akan mengkatalisis hidrolisis ikatan $\alpha$-D-galaktosidik yang terkandung dalam hemaktellulosa galaktooligosakarida (Fernandez, 2011). Adapun fungi yang memiliki enzim tersebut adalah Aspergills 
niger, Aspergillus fumigatus, Trichoderma viride, dan Saccharomyces cerevisiae. Fungi-fungi tersebut terbukti memiliki kemampuan untuk mendegradasi senyawa aromatik seperti coumaroyl amide, feruoyl amide, asam coumaric dan asam benzoat yang terkandung dalam lignin melalui jalur benzoyl-CoA. Penurunan lignoselulosa akan menghasilkan senyawa aromatik yang akan menghambat proses hidrolisis dan fermentasi. Fungi dapat mendegradasi senyawa aromatik secara anaerob tanpa merusak atau mengonsumsi glukosa dan xilosa yang diperlukan selama proses fermentasi (Wong, 2008). Kedua bahan tersebut terjangkau dan dapat diperoleh dengan mudah oleh masyarakat umum. Tujuan utama dari karya ilmiah ini adalah untuk mengevaluasi kegunaan limbah produksi keripik ketela, terutama limbah kulit ketela untuk bahan baku bioetanol, menggunakan perlakuan biologis agar ramah lingkungan. Oleh karena itu diperlukan adanya penelitian untuk mengetahui potensi dari fungi dalam merombak bahan baku menjadi etanol.

\section{TINJAUAN PUSTAKA}

\section{Limbah Kulit Ketela}

Menurut FAO, (2006) ketela adalah tanaman umbi-umbian populer di negara-negara tropis. Meskipun, penggunaan utama mereka adalah sebagai tanaman pangan, tanaman tersebut banyak digunakan untuk produksi pati, peran mereka telah semakin dikenal sebagai tanaman industri untuk produksi bioetanol, glukosa, dll (Baskar et al., 2008).

Ketela dapat dimanfaatkan dengan baik di berbagai industri yang memproduksi turunan pati dan pati beralkohol (Falade, A. et al, 2018). Peningkatan harga bahan bakar berbasis minyak bumi, peraturan pemerintah yang ketat tentang emisi gas buang dan penipisan cadangan minyak bumi di masa depan mendorong penelitian yang mencari bahan bakar alternatif (Hashem dan Darwish, 2010).

Pada tahun 2015 Indonesia mampu menghasilkan ketela sebanyak 22 juta ton (BPS, 2015). Sriroth (2010) melaporkan bahwa dari produk pengolahan ketela yang begitu besar dihasilkan limbah berupa kulit ketela yang biasanya hanya dibuang atau untuk campuran pakan ternak. Kulit ketela merupakan salah satu sumber bioetanol dari bahan berserat. Kulit ketela bisa berpotensi untuk diproduksi menjadi bietanol yang digunakan sebagai pengganti bahan bakar minyak. Adapun kulit ketela merupakan limbah dari tanaman ketela yang memiliki kandungan serat yang dapat digunakan sebagai sumber energi. Persentase jumlah limbah kulit bagian luar (berwarna coklat dan kasar) sebesar 0,5-2\% dari berat total ketela segar dan limbah kulit bagian dalam (berwarna putih kemerah-merahan dan halus) sebesar 8-15\% (Hikmiyatie, 2008).

\section{Pengenalan Etanol dan Bioetanol}

Sun (2009) mengatakan bahwa etanol (etil alkohol, bioetanol) termasuk dalam kelompok alkohol. Selama tahun-tahun awal, etanol disajikan sebagai minuman beralkohol. Kemudian pada tahun 1826, etanol digunakan sebagai bahan bakar lampu dan beberapa dekade setelah itu, bahan bakar etanol digunakan untuk menjalankan mobil (Baskar et al., 2008). Ada dua jenis etanol, yaitu etanol sintetis dan lainnya adalah bioetanol. Etanol sintetis adalah produk minyak bumi yang dapat diproduksi dengan mengkonversi etilen menggunakan uap dan katalis. Namun, bioetanol dihasilkan dari biofermentasi gula, yang merupakan proses yang akan dilakukan selama penelitian ini. Etanol membentuk karbon dioksida dan air ketika terbakar di udara dengan nyala biru yang hampir tidak terlihat.

Bioetanol adalah sumber energi terbarukan (diproduksi dari tanaman). Karenanya, tidak akan ada kekhawatiran tentang menipisnya sumber ini. Dengan mengacu pada JC Escobar, (2008) menyebutkan bahwa bioetanol didefinisikan oleh US DOE (United States Department of Energy) sebagai bahan bakar alternatif berbasis alkohol, diproduksi oleh fermentasi dan destilasi bahan baku dengan kandungan gula dan pati yang tinggi, misalnya ketela, umbi, kentang. Selain bahan baku ini, etanol dapat diperoleh dari biomassa istilah-selulosa atau disebut sebagai biomassa yang tidak dapat dimakan dari pohon dan beberapa tumbuhan (Hikmiyatie, 2008). Secara umum, ada beberapa teknologi yang berbeda untuk memproduksi bahan bakar etanol, mereka berasal dari stok pakan yang mengandung sukrosa (terutama tebu), bahan bertepung, biomassa lignoselulosa dan makroalga (Kumar, 2018). 
Faktor yang dapat mempengaruhi banyaknya bioethanol dari hasil penelitian sebelumnya bahwa yang dihasilkan dari fermentasi adalah hasil glukosa yang optimum untuk reaksi hidrolisa dengan $\mathrm{H}_{2} \mathrm{SO}_{4}$ yaitu $0,3 \mathrm{M}$ dan waktu fermentasi yang optimum pada proses fermentasi adalah 96 jam dimana dihasilkan etanol sebesar 1,95\% (v/v) dengan densitas 1,052 gr/mL (Hikmiyati dan Yanie, 2009).

\section{Fermentasi Etanol}

Kumar (2018) mengatakan bahwa fermentasi etanol adalah proses biologis di mana glukosa $\left(\mathrm{C}_{6} \mathrm{H}_{12} \mathrm{O}_{6}\right)$ dikonversi menjadi energi seluler dan dengan demikian menghasilkan etanol dan karbon dioksida sebagai produk limbah metabolisme. Secara umum, setiap bahan baku yang terdiri dari gula mampu menghasilkan etanol.

Ada beberapa jenis mikroorganisme yang digunakan untuk mengubah glukosa menjadi etanol. Saccharomyces cerevisiae adalah mikroorganisme yang umum digunakan yang digunakan karena kemampuannya untuk menghidrolisis pati menjadi glukosa dan fruktosa (Erna, 2016).

Bahan baku yang berbeda terdiri dari gula akan mengalami proses fermentasi yang sama dan menghasilkan etanol tetapi mereka akan memiliki metode produksi yang berbeda. Berdasarkan CF Gonzalez, JI Farina, LIC de Figueroa (2008) mengatakan bahwa pati ketela terdiri dari amilase tidak bercabang $(20 \pm 5 \%)$ dan amilopektin bercabang $(80 \pm 5 \%)$ yang keduanya dapat dihidrolisis baik dengan asam maupun enzimatis (baik dengan enzim murni atau mikroorganisme penghasil amilase) untuk melepaskan glukosa dan maltoologosaccharides (gula pereduksi). Setelah itu, kedua produk dapat mengangkut melintasi membran sel dan dimetabolisme oleh ragi. Singkatnya, hidrolisis adalah proses menghidrolisis polimer glukosa menjadi gula yang dapat difermentasi oleh aksi enzim.

Saccharomyces cerevisiae merupakan salah satu spesies ragi yang memiliki daya konversi gula menjadi bioetanol dengan baik (Erna, 2016). Mikroba ini biasanya dikenal dengan baker's yeast dan metabolismenya telah dipelajari dengan baik. Produk metabolik utama adalah bioetanol, $\mathrm{CO}_{2}$, dan air sedangkan beberapa produk lain dihasilkan dalam jumlah sangat sedikit. Ragi ini bersifat fakultatif anaerobik. Saccharomyces cerevisiae memerlukan suhu $30^{\circ} \mathrm{C}$ dan $\mathrm{pH} 4,0-4,6$ agar dapat tumbuh dengan baik. Ragi tumbuh optimum pada suhu $25-30^{\circ} \mathrm{C}$ dan maksimum pada $35-47^{\circ} \mathrm{C}$. Nilai $\mathrm{pH}$ untuk pertumbuhan ragi yang baik antara 3-6. Perubahan $\mathrm{pH}$ dapat mempengaruhi pembentukan hasil samping fermentasi. Pada $\mathrm{pH}$ tinggi maka konsentrasi gliserin akan naik dan juga berkorelasi positif antara $\mathrm{pH}$ dan pembentukan asam piruvat. Pada $\mathrm{pH}$ tinggi maka lag phase akan berkurang dan aktivitas fermentasi akan naik (Winjaya, 2011).

Tabel 1. Hasil Penelitian

\begin{tabular}{lll}
\hline \multicolumn{1}{c}{ Judul Paper, tahun } & \multicolumn{1}{c}{ Penulis } & \multicolumn{1}{c}{ Hasil Penelitian } \\
\hline Produksi Bioetanol dengan & R.G Witantri, T. Purwoko, & $\bullet$ EM4 3\% pada hari keempat menghasilkan \\
Memanfaatkan Limbah & Sunarto, E. Mahajoeno & etanol sebanyak 3.3\% (v/v). \\
Kulit Ketela melalui & & - Rhodopseumonas palustris, Lactobacillus \\
Proses Hidrolisis & casei, and Saccharomyces cerevisiae pada \\
Enzimatis dan & hari keempat menghasilkan etanol sebanyak \\
Mikroorganisme, 2017 & & $2.45 \%(\mathrm{v} / \mathrm{v})$. \\
& - Enzim selulosa pada hari keempat \\
& menghasilkan etanol 2.61\% (v/v).
\end{tabular}

\begin{tabular}{|c|c|c|}
\hline $\begin{array}{l}\text { Pembuatan Etanol Dari } \\
\text { Limbah Ampas Kelapa } \\
\text { Dengan Menggunakan } \\
\text { Rhizopus oligosporus Dan } \\
\text { Saccharomyces cerevisae } \\
\text { Dengan Penambahan } \\
\text { Phospat, } 2012\end{array}$ & $\begin{array}{l}\text { H.Widyatmoko, } \\
\text { Anindya Duhita }\end{array}$ & $\begin{array}{l}\text { - Nilai kadar etanol paling tinggi adalah } 1.14 \% \\
\text { (v/v) yaitu ampas kelapa yang sudah di } \\
\text { kupas. } \\
\text { - Nilai kadar etanol paling rendah adalah } \\
0.46 \%(\mathrm{v} / \mathrm{v}) \text { yaitu ampas kelapa yang belum } \\
\text { di kupas }\end{array}$ \\
\hline $\begin{array}{l}\text { Bioetanol Dari Limbah } \\
\text { Kulit Singkong (Manihot } \\
\text { esculenta crantz) Melalui } \\
\text { Proses Fermentasi, } 2016\end{array}$ & $\begin{array}{l}\text { Erna, Irwan Said, dan P. } \\
\text { Hengky Abram }\end{array}$ & $\begin{array}{l}\text { - Saccharomyes cerevisae digunakan untuk } \\
\text { memfermentasikan substrat. } \\
\text { - Etanol yang dihasilkan pada hari keempat } \\
\text { sebesar } 4.5 \%(\mathrm{v} / \mathrm{v}) \text {. } \\
\text { - Etanol yang dihasilkan pada hari keenam } \\
\text { sebesar } 5.2 \%(\mathrm{v} / \mathrm{v}) \text {. }\end{array}$ \\
\hline
\end{tabular}


- Etanol yang dihasilkan pada hari kedelapan $6 \%(\mathrm{v} / \mathrm{v})$.

- Etanol yang dihasilkan pada hari kesepuluh $4 \%(\mathrm{v} / \mathrm{v})$.

\section{PENUTUP}

Dapat disimpulkan bahwa bahan baku limbah kulit ketela memiliki kondisi yang dapat dimanfaatkan untuk produksi bahan bakar melalui proses enzimatis yang ramah lingkungan karena memanfaatkan mikroorganisme seperti fungi untuk menghidrolisis limbah kulit ketela. Adapun fungi terbaik yang dapat membantu menjadikan pembentukan etanol menjadi tinggi adalah Aspergillus fumigatus dan Saccharomyces cerevisae yang dapat di panen pada hari kedua menghasilkan etanol sebesar 3.76\% (v/v). sehingga diperlukan penelitian lebih lanjut untuk mengetahui pembentukan enzim dari fungi tersebut.

\section{DAFTAR PUSTAKA}

A. Rinanti et al., (2015). Pengolahan Limbah Padat Tapioka Menjadi Etanol dengan Menggunakan Aspergillus niger, Bacillus licheniformis dan Saccharomyces cerevisiae. JTL Vol. 7 No. 1 Juni 2015, $17-23$.

DOI: http://dx.doi.org/10.25105/urbanenvirotech.v7i1.712

Artiyani, A., \& Soedjono, E. S. (2011). Bioetanol Dari Limbah Kulit Ketela Melalui Proses Hidrolisis Dan Fermentasi Dengan Saccharomyces cerevisae. Prosiding Seminar Nasional Manajemen Teknologi XIII. Surabaya: FTSP Institut Teknologi Sepuluh Nopember.

Badan Pusat Statistik, 2017, "Produksi Tumbuhan Ketela dari Propinsi (ton) per tahun 1993 2015"

Baskar, G., Muthukumaran, C., \& Renganahan, C. (2008). Optimalisasi hidrolisis enzimatik pati akar Manihot esculenta dengan amobil $\alpha$-amilase menggunakan metodologi respon permukaan. International Journal of Chemical and Biomolecular Engineering, 1, 3. www.waset.orgsummer 2008.

C.F. González, J.I. Fariña, L.I.C. de Figueroa (2008). Mengoptimalkan produksi enzim amilolitik di Saccharomycopsis fibuligera DSM-70554, Suatu pendekatan untuk pemanfaatan pati singkong yang efisien. Enzymes and Microbial Technology 42, 272-277.

Erna., S., Said, \& H., Abram. (2016). Bioetanol Dari Limbah Kulit Singkong (Manihot esculenta Crantz) Melalui Fermentasi. ISSN 2302-6030 (p), 2477-5185 (e).

Fachry A R, Astuti P and Puspitasari T G. 2013. Jurnal Teknik Kimia 1960

Falade, A. O., Mabinya, L. V., Okoh, A. I., \& Nwodo, U. U. (2018). Enzim ligninolitik: Biokatalis serbaguna untuk menghilangkan bahan kimia yang mengganggu endokrin dalam air limbah. Microbiology Open, e00722.

DOI: $10.1002 / \mathrm{mbo} 3.722$

FAO Buku Tahunan Produksi (2006), Rome, Italy.

Fernandez M B, Gulshan A 2014. Produksi Bioetanol dan Protein Rekombinan dari Milk Whey dan Molase. Italy: University of Coruna)

H.Widyatmoko et al., (2012). Pembuatan Etanol dari Limbah Ampas Kelapa dengan Menggunakan Rhizopus oligosporus dan Saccharomyces cereviseae dengan Penambahan Phospat. JTL Vol 6 No. 1 C Desember 2012, 15-22.

DOI: http://dx.doi.org/10.25105/urbanenvirotech.v6i1.699

Hashem, M., Darwish, S.M.I., 2010. Produksi bioetanol dan produk samping terkait dari aliran residu pati kentang oleh Saccharomyces cerevisiae. Biomass bioenergy 34, 953-959.

Hikmiyati, N. \& Yanie, N. S. 2008 Pembuatan bioetanol dari limbah kulit singkong melalui proses hidrolisis asam dan enzimatik. Fakultas Teknik, Jurusan Teknik Kimia. Semarang: Universitas Diponegoro.

Novia N, Faizal M, Ariko M F and Yogamina D H. 2011. Prosiding Seminar Nasional 3 451-462

Prasad, R. K., Chatterjee, S., Mazumder, P. B., Gupta, S. K., Sharma, S., Vairale, M. G., Gupta, D. K. (2018). Produksi bioetanol dari limbah lignoselulosa: Tinjauan potensi degradasi mikroba. Chemosphere.

DOI: $10.1016 /$ j.chemosphere.2019.05.142 
Sarkar, N., Ghosh, S. K., Bannerjee, S. \& Aikat, K. (2011). Produksi bioetanol dari limbah pertanian: Tinjauan umum. Jurnal Energi Terbarukan, 37, 19-27.

Sun, Y. and J. Cheng. 2009. Hidrolisis bahan lignoselulosa untuk produksi etanol: Tinjauan umum. Bioresour. Technol. 83: 1-11.

Winjaya, I Nyoman P, dkk. 2011. Proses Treatment Dengan Menggunakan NaOCl dan H2SO4 Untuk Mempercepat Pembuatan Bioetanol Dari Limbah Rumput Laut Eucheuma Cottonii. Universitas Udayana. Bali.

Wong, D. W. S. (2008). Struktur dan Mekanisme Aksi Enzim Ligninolytic. Biokimia dan Bioteknologi Terapan, 157(2), 174-209.

DOI: $10.1007 / \mathrm{s} 12010-008-8279-\mathrm{z}$ 